\title{
METODE TAHFIDZ AL-QUR'AN DI PONDOK PESANTREN KABUPATEN KAMPAR
}

\author{
Ali Akbar dan Hidayatullah Ismail \\ UIN Sultan Syarif Kasim Riau \\ ali.akbar@uin-suka.ac.id
}

\begin{abstract}
This paper discusses the Method of Tahfidz Al-Quran at the Boarding Schools in the Regency of Kampar. The method used in fostering students at the Boarding Schools of this Regency was the focus of this study. It was a qualitative approach which was conducted at the Boarding School of Daarun Nahdhah, Al-Badr, the Ansar al-Sunnah, Daar al-Salafi, Sabil al-Salam and al-Taufik. Interview, documentation and observation were the instrumentations used in this study. It was found that the boarding schools in the regency of Kampar used various methods in nurturing students to employ activities of tahfizd al-Qur'an, by means of reading carefully and repeatedly to memorize verse-by-verse without neglecting the Mushaf (annadzar), memorizing verse-by-verse over and over and finally the students could learn by heart (al-Wahdah), depositing or listening what the students had newly been memorized to a teacher (talaqqi), memorizing piecemeal of the Qur'anic verses and read the verses repeatedly (takrir) and listening the memorized verses to others, i.g. both to friends and other congregation (tasmi').
\end{abstract}

Keywords: Al-Quran, Tahfidz, and Pondok Pesantren

\begin{abstract}
Abstrak
Tulisan ini membahas tentang "Metode Tahfidz al-Qur'an di Pondok Pesantren Kabupaten Kampar". Fokus kajiannya adalah metode yang digunakan Pondok Pesantren di Kabupaten Kampar dalam membina santrinya mengikuti tahfizd al-Qur'an. Penelitian dilakukan dengan pendekatan kualitatif, dengan fokus kajian beberapa Pondok Pesantren di Kabupaten Kampar, yaitu; Pondok Pesantren Daarun Nahdhah, Al-Badr, Anshar al-Sunnah, Daar alSalafi, Sabil al-Salam, dan al-Taufik. Pengumpulan data dilakukan dengan teknik wawancara, dokumentasi, dan observasi. Hasil penelitian menemukan bahwa pondok pesantren di Kabupaten Kampar menggunakan berbagai metode dalam membina santrinya mengikuti kegiatan tahfizd al-Qur'an, yaitu dengan cara; membaca secara cermat ayat per-ayat al-Qur'an yang akan dihafal dengan melihat mushaf secara berulang-ulang (annadzar), menghafal ayat per ayat secara berulang sehingga akhirnya hafal (al-wahdah), menyetorkan atau mendengarkan hafalan yang baru dihafal kepada seorang guru (talaqqi), menghafal sedikit demi sedikit al-Qur'an yang telah dibaca secara berulang-ulang (takrir) dan mendengarkan hafalan kepada orang lain, baik kepada teman maupun kepada jama'ah lain (tasmi').
\end{abstract}

Kata kunci: Al-Qur'an, Tahfidz, dan Pondok Pesantren 


\section{Pendahuluan}

A1-Qur'an merupakan petunjuk dan pedoman bagi umat manusia dalam menghadapi segala persoalan hidup dan kehidupannya sepanjang zaman, yang tak layu oleh waktu dan tak lekang oleh zaman, serta - meminjam istilah Quraish Shihab - dapat berdialog dengan seluruh generasi manusia, ${ }^{1}$ guna memperoleh kebahagiaan hidup di dunia maupun akhirat.

Sebagai petunjuk dalam kehidupan umat Islam, al-Qur'an tidak hanya cukup dengan membaca dengan suara yang indah dan fasih, tetapi selain memahami harus ada upaya konkret dalam memeliharanya, baik dalam bentuk tulisan maupun hafalan. Al-Qur'an tidak boleh dibiarkan begitu saja sebagai koleksi atau apapun nama dan bentuknya, tanpa penjagaan dan pemeliharaan yang serius dari umatnya.

Umat Islam berkewajiban memelihara dan menjaganya, antara lain adalah dengan membaca (al-tilawah), menulis (al-kitabah) dan menghafal (at-tahfidz), sehingga wahyu tersebut senantiasa terjaga dan terpelihara dari perubahan dan penggantian, baik huruf maupun susunan katakatanya sepanjang masa. Allah Swt. menyebutkan dalam firman-Nya:

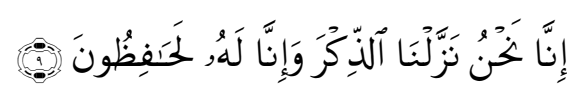

Artinya: "Sesungguhnya Kami-lah yang menurunkan al-Qur'an, dan Sesungguhnya Kami benar-benar memeliharanya" (QS. alHijr : 9). ${ }^{2}$

Berdasarkan ayat tersebut, Allah Swt. memberikan garansi bahwa Dia senantiasa menjaga al-Qur'an sepanjang masa. Penjagaan Allah Swt. terhadap al-Qur' an bukan berarti Allah

\footnotetext{
${ }^{1}$ Muhammad Quraish Shihab, dalam Pengantar, YunanYusuf, Corak Pemikiran Kalam Tafsir al-Azhar (Jakarta: Pustaka Panjimas, 1990), v.

${ }^{2}$ Departemen Agama RI, Al-Qur'an dan Terjemahnya (Jakarta:Toha Putra, t.th), 391. Selanjutnya ayat-ayat diterjemahkan dengan referensi yang sama.
}

Swt. menjaga secara langsung fase-fase penulisan al-Qur'an, tetapi melibatkan para hamba-Nya untuk ikut menjaga al-Qur'an tersebut. Salah satu bentuk realisasinya adalah Allah Swt. mempersiapkan manusia-manusia pilihan yang akan menjadi penghafal al-Qur'an dan penjaga kemurnian kalimat serta bacaannya. Sebab memelihara kesucian dengan menghafalkannya adalah pekerjaan yang terpuji dan amal yang mulia, yang sangat dianjurkan Rasulullah. ${ }^{3}$

Pada masa Nabi Muhammad Saw. menerima wahyu al-Qur'an dari Allah Swt., bangsa Arab sebagian besar buta aksara (tidak pandai membaca dan menulis). Mereka belum banyak mengenal kertas sebagai alat tulis seperti sekarang, begitu pula membacanya. Oleh karena itu, setiap Nabi Saw. menerima wahyu selalu dihafalnya, kemudian beliau menyampaikan kepada para sahabat dan diperintahkannya pula untuk menghafal dan menuliskan di batu-batu, pelepah kurma, kulit-kulit binatang dan apa saja yang bisa dipakai untuk menulisnya ${ }^{4}$ pada masa itu. Tradisi pemeliharaan al-Qur'an dalam bentuk hafalan khususnya terus berlanjut dari generasi ke generasi hingga sampai sekarang. Dorongan untuk menghafal al-Qur'an sendiri telah dijelaskan dalam firman-Nya:

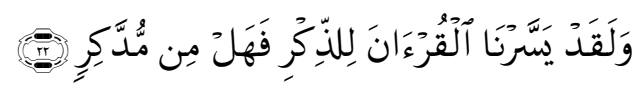

Artinya: "Dan sesungguh, telah kami mudahkan al-Qur'an untuk peringatan maka adakah orang yang mengambil pelajaran?"(QS. al-Qamar: 22).

Ayat ini mengindikasikan kemudahan dalam menghafal al-Qur'an, karena Allah Swt. akan memberi pertolongan dan kemudahan bagi para penghafal al-Qur'an. Sebab memelihara kesucian

${ }^{3}$ Perguruan Tinggi Ilmu Al-Qur'an, Beberapa Aspek Ilmiah Tentang Qur'an (Jakarta: Litera Antarnusa, 1986), 137. ${ }^{4}$ Muhaimin Zen, Tata Cara/Problematika Menghafal AlQur'an dan Petunjuk-Petunjuknya (Jakarta: PT Maha Grafindo, 1985), 5-6. 
dengan menghafalkannya adalah pekerjaan yang terpuji dan amal yang mulia, yang sangat dianjurkan agama. Dalam sebuah hadits redaksi dari Bukhari disebutkan bahwa "Perumpamaan orang yang memnbaca al-Qur'an dan menghafalnya adalah bersama para maliakat yang mulia dan ta'at" Bahkan menghafal alQur'an merupakan salah satu metode yang digunakan Rasulullah Saw. dalam menerima wahyu melalui perantaraan Jibril as.

Menghafal al-Qur'an bukanlah tugas dan perkara yang mudah, artinya tidak semudah membalikkan telapak tangan. Salah satu upaya terpenting diperhatikan dalam pembinaan tahfizh al-Qur'an adalah metode. ${ }^{5}$ Sebab metode mempunyai peranan penting dan sangat dibutuhkan. Dengan adanya metode akan bisa membantu seseorang untuk menentukan keberhasilan belajar menghafal al-Qur'an dan meningkatkan hafalannya secara terprogram. Di samping juga diharapkan nantinya dapat membantu hafalan menjadi efektif.

Di zaman yang serba canggih pada saat ini, ditemukan banyak sekali metode yang bisa digunakan untuk membantu proses penghafalan al-Qur'an. Metode efektif yang digunakan penghafalan al-Qur'an beragam, ada dengan cara; membaca secara cermat ayat-ayat al-Qur' an yang akan dihafal dengan melihat mushaf secara berulang-ulang (an-nadzar), menyetorkan atau mendengarkan hafalan yang baru dihafal kepada seorang guru (talaqqi), menghafal sedikit demi sedikit al-Qur'an yang telah dibaca secara berulang-ulang (takrir), mendengarkan hafalan kepada orang lain baik kepada teman maupun kepada jama'ah lain (tasmi'), dan sebagainya. Kemudian dalam melaksanakan metode tahfidz al-Qur'an hendaknya dipandu dan dibimbing

\footnotetext{
${ }^{5}$ Winarno Surakhmad menyebutkan metode adalah cara yang di dalam fungsinya merupakan alat untuk mencapai tujuan tertentu, makin baik metode itu makin efektif pula pencapaian tujuan. Lihat Winarno Surakhmad, Pengantar Interaksi Mengajar-Belajar Dasar dan Teknik Metodelogi Pengajaran (Bandung: Tarsito, 1982), 96.
}

lansung oleh pemandu tahfidz yang berkompeten dalam penghafalan al-Qur'an, supaya hafalan yang sudah didapatkan bisa dipantau dan dibina oleh pemandu tahfidz bila ada kesalahan dan sebagainya.

Demikian pula di Kabupaten Kampar khususnya, pada masa sekarang telah tumbuh subur lembaga-lembaga pendidikan Islam yang memberikan kesempatan kepada putra-putri di daerahnya mendalami nilai-nilai agama guna membentuk kepribadian muslim yang beriman dan bertakwa kepada Swt., berakhlak mulia, bermanfaat bagi kemajuan pembangunan bangsa dan negara. Misalnya, pesantren Daarun Nahdhah, Daarul Qur'an, Anshar al-Sunnah, Daar al-Salafi, Sabil al-Salam, al-Taufik, dan lainnya. Selain memberikan kesempatan kepada para santrinya mendalami nilai-nilai agama, di pesantrenpesantren tersebut juga mendidik para santrinya menguasai ilmu al-Qur'an dengan melaksanakan program unggulan membimbing santrinya menjadi huffazh (para penghafal al-Qur'an).

Untuk mencapai tujuannya di bidang pembinaan tahfidz al-Qur'an dibutuhkan suatu strategi dan cara yang cocok, sehingga tujuan yang diinginkan dapat tercapai. Demikian pula dengan pelaksanaan menghafal al-Qur'an, memerlukan suatu metode dan teknik yang dapat memudahkan usaha-usaha tersebut, sehingga dapat berhasil dengan baik. Oleh karena itu, metode merupakan salah satu faktor yang turut menentukan keberhasilan dalam menghafal al-Qur'an, khususnya bagi para santri pondok pesantrem di Kabupaten Kampar.

\section{Metode Penelitian}

Penelitian ini adalah penelitian lapangan (field research), karena kegiatan ini dilakukan di pondok pesantren yang ada di Kabupaten Kampar. Secara umum yang menjadi alasan penulis memilih lokasi Kabupaten Kampar, selain karena pertimbangan waktu dan biaya ada beberapa pertimbangan lain; pertama, karena penduduk di Kabupaten Kampar mayoritas beragama Islam, dan mereka taat menjalankan ajaran-ajaran agama 
dalam kehidupan sehari-hari. Kedua, di daerah ini terdapat beberapa Pondok Pesantren yang mempunyai program unggulan di bidang tahfidz al-Qur'an (penghafalan al-Qur'an) serta telah mendapat predikat baik di bidang agama khususnya pembelajaran al-Qur'an. Ketiga, sampai saat penulis melakukan penelitian pendahuluan belum ada penelitian spesifik yang membahas tentang metode tahfidz al-Qur'an di Kabupaten Kampar Riau tersebut.

Penelitian ini menggunakan pendekatan kualitatif, yaitu jenis pendekatan penelitian yang tidak melibatkan perhitungan. Sumber data yang diperlukan dalam penelitian ini terdiri dari data primer dan data sekunder. Data sekunder diperoleh dari bahan-bahan kepustakaan, meliputi bahan hukum primer dan bahan hukum sekunder. Sedangkan data primer diperoleh dari nara sumber di lapangan melalui wawancara, observasi, dan dokumen. Dalam wawancara peneliti berinteraksi langsung dengan informan wawancara dilakukan terhadap kyai, pimpinan pondok, santri, dan ustad/ ustadzah pengampu kegiatan tahfizd.

\section{Pondok Pesantren Sebagai Setting Penelitian di Kabupaten Kampar}

Pada bagian ini akan digambarkan sekilas tentang kondisi umum pondok pesantren disebut di atas. Kondisi umum yang penulis maksud adalah uraian singkat mengenai situasi dan kondisi Pondok Pesantren di Kabupaten Kampar, yang kemudian dijadikan lokasi penelitian oleh penulis yang meliputi; sejarah berdirinya, tujuan berdiri, visi dan misi, dan metode pelaksanaan kegiatan tahfidz al-Qur'an yang diterapkan pondok pesantren bagi santrinya.

\section{Pondok Pesantren Daarun Nahdhah Bangkinang}

Berdasarkan observasi dan wawacara, ${ }^{6}$ didapati informasi bahwa Pondok Pesantren

${ }^{6}$ Drs. H. Rusydinur (wakl pimpinan pondok), wawancara tanggal 10 September 2015.
Daarun Nahdhah Thawalib Bangkinang merupakan pesantren tertua di Kabupaten Kampar, bahkan di Provinsi Riau. Pondok Pesantren Daarun Nahdhah Thawalib Bangkinang merupakan kelanjutan dari Madrasah Daarul Mu'allimin pimpinan Syeh H. Abdul Malik, yang dulunya lebih akrab disebut "thawalib/kutab" yang didirikan pada tahun 1923, dengan menggunakan sistem pendidikan halaqah dan klasikal. Namun kemudian, karena penjajahan Jepang masuk ke wilayah tersebut membuat proses pendidikan di Daarul Mu'allimin terhenti.

Akhirnya salah seorang murid almarhum Syekh Abdul Malik yang bernama almarhum KH. M. Noer Mahyuddin mengambil prakarsa untuk menghidupkan kembali madrasah tersebut. Beliau mengumpulkan sejumlah ulama dan tokoh masyarakat sekitarnya (Desa Muara Uwai tempat kelahirannya) untuk membicarakan kemungkinan berdirinya lembaga pendidikan berupa pondok pesantren. Kehadiran pondok tersebut - menurut beliau- akan sangat banyak manfaatnya bagi generasi muda Islam di wilayah tersebut untuk masa datang.

Hasil musyawarah disepakati untuk mendirikan sebuah lembaga pendidikan. Akhirnya pada tanggal 11 Januari 1948 dibawah kepemimpinan KH. Muhammad Noer Mahyuddin berdiri kembali pondok, dengan nama Pondok Pesantren Daarun Nahdhah Thawalib Bangkinang (disingkat PPDN-TB). Pada mulanya pendirian tersebut ditandai dengan penerimaan santri baru untuk tingkat Ibtida'iyah saja. Kemudian pada tanggal 18 Agustus 1948 pesantren tersebut membuka jenjang pendidikan tingkat Tsanawiyah dan Aliyah hingga sekarang.

Sejarah kembali berulang, belum genap pesantren itu berumur satu tahun, meletus pula agresi Belanda pada 31 September 1948. Agresi Belanda tersebut membuat para guru dan murid terpaksa mengungsi. Bahkan tak sedikit pula yang ikut bergerilya mempertahankan kemerdekaan, sehingga dikabarkan salah seorang guru pesantren tewas di tangan Belanda masa itu. 
Setelah masa agresi Belanda selesai, pada tanggal 27 Desember 1950 almarhum KH. Muhammad Noer Mahyuddin kembali mengumpulkan para guru dan santri untuk melanjutkan kembali kegiatan pendidikan di pondok pesantren Daarun Nahdhah tersebut. Sekarang pesantren tersebut dipimpin oleh putra beliau Drs. H. Syahrizulnur. Pesantren ini terletak di Kecamatan Bangkinang Seberang, tak jauh dari pusat/ibu kota Kabupaten Kampar, tepatnya J1. Syarifuddin Syarif, SH Bangkinang Seberang.

Sebagai sebuah lembaga pendidikan keagamaan, Pondok Pesantren Daarun Nahdhah Bangkinang telah berperan aktif dalam mencerdaskan kehidupan bangsa, yakni memberikan pendidikan keislaman kepada para santrinya; mulai dari nahwu, sharaf, fiqih, tafsir, mantiq, akhlak, tauhid, dan mata pelajaran lainnya. Selain itu, pesantren juga memberikan pendidikan umum sesuai dengan perkembangan. Sebagian besar santrinya dididik secara formal di asrama dan mengikuti berbagai kegiatan pondok yang sudah ditentukan.

Pondok Pesantren Daarun Nahdhah Bangkinang, selain membekali para santrinya dengan pengetahuan agama dan umum, juga keterampilan membaca kitab kuning dan hafalan al-Qur'an mulai dari Tingkat Tsanawiyah hingga Aliyah. Penghafalan al-Qur'an merupakan program penting dan wajib diikuti oleh setiap santri sesuai dengan peringkatnya.

Adapun visi Pondok Pesantren Daarun Nahdhah adalah terwujudnya lembaga pendidikan sebagai pusat pembentukan sumber daya manusia yang beriman, bertaqwa, berakhlakul karimah, menguasai ilmu pengetahun dan teknologi serta berwawasan lingkungan. Sedangkan misinya, antara lain:

a. Melaksanakan sistem pendidikan Islam.

b. Menumbuhkembangkan semangat menuntut ilmu dan penguasaan teknologi.

c. Melaksanakan proses pembelajaran yang efektif dan efisien, bermuatan kurikulum berbasis lingkungan hidup untuk melahirkan insan yang cerdas, disiplin dan berkualitas.

Sedangkan tujuan yanya ingin dicapai antara lain:

a. Santri mampu membaca dan memahami teksteks arab gundul.

b. Berjaya dalam kegiatan MTQ dan MQK.

c. Berjaya dalam penerapan ilmu pengetahuan dan teknologi, sains, dan matematika.

d. Berjaya dalam memberikan pelayanan dan informasi pada siswa, orang tua dan masyarakat. $^{7}$

\section{Pondok Pesantren Al-Badr Bangkinang}

Berdasarkan observasi dan wawancara, ${ }^{8}$ Pondok Pesantren Al-Badr berdiri pada tahun 1990 yang dipelopori oleh almarhum Drs. Bustami Jali, BA, dan sekarang dilanjutkan oleh putra-putri beliau dibawah kepemimpinan Drs. Alyasser. Pesantren ini terletak di jantung ibu kota Kabupaten Kampar Bangkinang, tepatnya Jl. Jend. Sudirman Bangkinang. Berdirinya pesantren ini dilatari oleh keinginan pimpinan/pendiri pondok dan semangat masyarakat Bangkinang khususnya untuk mendirikan lembaga pendidikan yang dapat menampung generasi-generasi yang Islamy atau mencetak ulama.

Sebagai sebuah lembaga pendidikan keagamaan, Pondok Pesantren Al-Badr telah berperan aktif dalam mencerdaskan kehidupan bangsa. Selain membekali para santrinya dengan pengetahuan agama dan umum, juga keterampilan membaca kitab kuning dan hafalan al-Qur'an. Para santri diwajibkan memiliki hafalan al-Qur'an sesuai dengan peringkatnya.

Adapun Visi Pondok Pesantren Al-Badr adalah menjadi lembaga pendidikan yang berkualitas, kreatif, dan inovatif pada semua disiplin ilmu untuk menampilkan keterpaduan

${ }^{7}$ http://ponpesdaarunnahdhah.sch.id/visi-dan-misi. Diakses pada pukul 22.30 WIB tanggal 12 Nopemebr 2015.

${ }^{8}$ Drs. Al-Yasser (pimpinan pondok), wawancara tanggal 10 September 2015; Dokumentasi PP-Al-Badr. 
IMTAQ (Iman dan Taqwa) dan IPTEK (Ilmu Pengetahuan dan Teknologi). Sedangkan misinya, adalah:

a. Melaksanakan pendidikan dengan sistem keterpaduan pada bidang kurikulum, pengelolaan dan qudwah.

b. Mewujudkan peserta didik yang berilmu, mandiri, dan berjiwa wiraswasta yang mampu menciptakan lapangan kerja di masyarakat.

\section{Pondok Pesantren Anshar As-Sunnah}

Berdasarkan observasi dan wawancara, ${ }^{9}$ diperoleh informasi bahwa Pondok Pesantren Anshar As-Sunnah berdiri pada tahun 2001 yang dipelopori oleh Ust. Herison, Lc. Pesantren ini terletak di Desa Air Tiris Kecamatan Kampar, tepatnya J1. Pasar Usang. Berdirinya pesantren ini dilatari oleh keinginan pimpinan/pendiri pondok dan semangat masyarakat setempat untuk mendirikan lembaga pendidikan yang dapat menampung generasi-generasi yang Islami atau mencetak ulama.

Adapun visi dan misi serta tujuan Pondok Pesantren Anshar al-Sunnah adalah terwujudnya masyarakat Madrasah Tsanawiyah Anshor AlSunnah yang ta'at, dinamis, rukun, berprestasi dan terampil, serta terwujudnya Madrasah Tsnawiyah Anshor Al-Sunnah sebagai lembaga pendidikan yang berkualitas dan unggul di Propinsi Riau dalam membentuk siswa/siswi yang hafidz dan hafidzah. Sedangkan misinya, antara lain:

a. Mewujudkan masyarakat yang Islami, berwawasan yang luas, berakhlak mulia, beriman dan bertaqwa.

b. Mewujudkan ketenagaan yang bekualitas, cerdas, loyal, inovatif, dan kreatif.

c. Mewujudkan masyarakat madrasah yang terampil serta dapat dirasakan mamfaatnya oleh masyarakat.

Pondok Pesantren Anshor Al-Sunnah

${ }^{9} \mathrm{H}$. Herison (pimpinan pondok), wawancara tanggal 11 September 2015; Dokumentasi Pondok Pesantren Anshor Al-Sunnah Air Tiris. bertujuan mendidik para santri agar membentuk insan yang bertaqwa dan berakhlak mulia dengan dibekali ilmu pengetahuan agama dan umum, serta pemahaman terhadap al-Qur'an dan Sunnah sesuai dengan Manhaj Ahlusunnah Wal Jama'ah yang diaplikasikan dalam kemampuan santri agar menjadi hafidz al-Qur'an, Hadits, Penguasaan Bahasa Arab serta Pemahaman Akidah yang benar dan pengembangannya menurut ulama salaf.

\section{Pondok Pesantren Ad-Daar al-Salafiyah al- Islamiyah}

Berdasarkan observasi dan wawancara, ${ }^{10}$ diperoleh informasi bahwa Pondok Pesantren adDar As-Salafiyah al-Islamiyah ini berdiri pada tanggal 26 Desember 1995. Pendirian pesantren ini berawal dari ide seorang putra daerah Kampar - Riau yang pernah mengenyam pendidikan di Kuwait - Timur Tengah selama beberapa tahun, yang bernama H. Zamzami, Lc., MA. Adapun faktor yang mendorong beliau untuk mendirikan lembaga pendidikan ini berawal dari keinginan untuk memperbaiki keadaan-keadaan yang terjadi di tengah-tengah masyarakat yang bertentangan dengan ketentuan al-Qur'an dan Sunnah, seperti perbuatan syirik, bid'ah, takhayyul dan khurafat, aliran-aliran sesat, dan lainnya yang menyebabkan mereka tenggelam dalam lautan kedurhakaan, sesuai dengan motto pesantren "Jalolah Badan jo Al-Qur'an dan As-Sunnah, Paliao Diri dari Syirik dan Ahlus Syirik, Kobek Salegho jo Manhaj Salaf."

Adapun visi pesantren ini mempersiapkan generasi muslim agar menjadi alim dan mukmin hakiki yang setia berdiri di atas tauhid dan Aqidah Salafus Shalih dan hidup di dalam manhaj generasi mulia (Shahabat, Tabi'in, Tabi'ut Tabi'in) serta menjauhkan mereka dari perbuatan syirik, ahlus syirik, takhayyul, bid'ah, khurafat, dan membekali mereka dengan akhlak yang mulia

${ }^{10}$ H. Zamzami, Lc., MA (pimpinan pondok), wawancara tanggal 11 September 2015; Dokumentasi Pondok Pesantren Ad-Daar al-Salafiyah al-Islamiyah. 
serta berhiaskan sabar dalam mengamalkan Dinul Islam yang mulia ini. Sedangkan misinya adalah menyebarluaskan kurikulum hidup yang Islami melalui:

a. Pendidikan mulai usia dini sampai usia lanjut.

b. Majlis ta'lim, dauroh intensif, atau dauroh ilmiyah di semua tingkatan usia.

c. Proyek-proyek Islam.

d. Usaha-usaha lainnya.

\section{Pondok Pesantren Sabil al-Salam}

Berdasarkan observasi dan wawancara, ${ }^{11}$ diperoleh informasi bahwa Pondok Pesantren Sabil al-Salam berdiri pada tahun 2006 yang dipelopori oleh Drs. M. Amin. Pesantren ini terletak di Kecamatan Kampar, tepatnya J1. Simpang Tibun Padang Mutung. Berdirinya pesantren ini dilatari oleh keinginan pimpinan/ pendiri pondok lembaga keagamaan guna menciptakan generasi ulama.

Awal mula dari pesantren ini, para santrinya berjumlah 9 orang yang terdiri dari lima laki-laki dan empat perempuan. Mulanya pesantren ini tidak memiliki asrama dan kelas untuk belajar, akan tetapi semangat dari pimpinan pondok tidak surut untuk tetap melaksanakan kegiatan belajar dan mengajar. Para santri dan santriwati menginap dan belajar di rumah pimpinan pondok selama enam bulan lamanya. Dan setelah itu barulah didirikan masjid berukuran sedang sebagai pusat kegiatan santri. Setelah setahun berjalan, barulah Pesantren ini mendirikan sebuah kelas untuk proses belajar mengajar dari dana pribadi pimpinan pondok, namun setelah dua tahun berjalan barulah mendapatkan bantuan berupa 3 kelas dari pemerintah daerah.

\footnotetext{
${ }^{11}$ Wawancara dengan pengasuh pondok Drs. M. Amin (pimpinan pondok), tanggal 12 September 2015 dan Sumber Dokumentasi Pondok Pesantren Sabil asSalam.
}

\section{Metode Pelaksanaan Tahfidz Al-Qur'an di Pondok Pesantren Kabupaten Kampar}

Metode atau yang biasa disebut juga cara merupakan hal sangat penting dalam mencapai keberhasilan, karena berhasil tidaknya suatu tujuan ditentukan oleh metode yang merupakan bagian integral dalam sistem pembelajaran. Banyak metode yang mungkin bisa dikembangkan dalam rangka mencari alternatif terbaik untuk menghafal al-Qu'an, bahkan bisa memberikan bantuan kepada para penghafal dalam mengurangi kesulitan menghafal alQur'an.

Kegiatan Tahfidz al-Qur'an pada Pondok Pesantren di Kabupaten Kampar merupakan kegiatan yang wajib diikuti para santri. Bahkan ada yang memasukkan tahfidz ini ke dalam komponen mata pelajaran pondok. Kegiatan penghafalan al-Qur'an tidaklah sama dan semudah mengajarkan mata pelajaran lain. Masing-masing pesantren melaksanakan kegiatan tahfidz al-Qur'an dengan metode yang berbeda.

Berdasarkan observasi dan wawancara yang dilakukan kepada beberapa orang pengasuh dan peserta tahfidz al-Qur'an di Pondok Pesantren Kabupaten Kampar, didapati informasi bahwa metode pelaksanaan Tahfidz al-Qur'an dari masing-masing pesantren dapat diekspresikan sebagai berikut:

1. Penghafalan al-Qur'an dengan cara menghafal ayat per-ayat secara kolektif, yakni ayat-ayat dihafal secara kolektif atau bersama-sama, dipimpin seorang instruktur. Caanya pertama, instruktur membacakan satu ayat atau beberapa ayat dan santri menirukan secara bersama-sama. Kedua, instruktur membimbingnya dengan mengulang kembali ayat-ayat tersebut dan santri mengikutinya. Setelah ayat-ayat itu dapat mereka baca dengan baik dan benar, selanjutnya mereka mengikuti bacaan dengan sedikit demi sedikit mencoba melepaskan mushaf (tanpa melihat mushaf) dan demikian seterusnya sehingga ayat-ayat yang sedang dihafalnya itu benar- 
benar sepenuhnya masuk dalam bayangannya. ${ }^{12}$ Pondok Pesantren yang menggunakan metode seperti adalah Pondok Pesantren Daarun Nahdhah, yang mana ustadz/pengampu membacakan ayat-ayat tersebut di hadapan santrinya, kemudian para santri menirukan bacaan ustazd/pengampu secara bersama-sama dan berulang-ulang, sehingga secara perlahan-lahan santri bisa membaca ayat-ayat yang sedang dihafalnya tanpa melihat mushaf karena benar-benar dalam sudah ada dalam bayangannya. Cara ini termasuk metode yang baik untuk dikembangkan, karena akan dapat menghilangkan kejenuhan, di samping akan membantu menghidupkan daya ingat terhadap ayat-ayat yang dihafalnya.

2. Pelaksanaan tahfidz al-Qur'an dengan menggunakan metode wahdah, yakni menghafal satu per satu terhadap ayat-ayat yang hendak dihafalnya. Untuk mencapai hafalan awal setiap ayat bisa dibaca sebanyak sepuluh kali, atau lebih sehingga proses ini mampu membentuk pola dalam bayangannya. Dengan demikian, penghafal akan mampu mengkondisikan ayat-ayat yang dihafalnya bukan saja dalam bayangan akan tetapi hingga membentuk gerak refleks pada lisannya. Setelah benar-benar hafal barulah dilanjutkan pada ayat-ayat berikutnya dengan cara yang sama, demikian seterusnya hingga mencapai satu muka. ${ }^{13}$ Cara seperti ini diikuti oleh Pondok Pesantren Al-Badr, di mana santri menghafal ayat per ayat secara sendiri-sendiri dan berulang, sehingga akhirnya bisa hafal. Kemudian untuk muraja'ah digunakan cara takrir, artinya santri mengulang kembali hafalan yang sudah pernah dihafalkan untuk menjaga dari lupa dan salah. Hafalan yang sudah pernah dipedengarkan kepada ustadz/

\footnotetext{
${ }^{12} \mathrm{~W}$. Ahsin Al-Hafizh, Bimbingan Praktis Menghafal AlQur'an (Jakarta: Bumi Aksara, 2000), 63.

${ }^{13}$ Ibid., 64.
}

ah atau kiyai diulang-ulang terus dengan dilakukan sendiri ataupun meminta bantuan orang lain untuk mendengarkan dan mengoreksi.

3. Cara yang seperti ini termasuk ke dalam metode yang banyak digunakan oleh para penghafal al-Qur'an, karena akan memudahkan penghafal, kemudian bacaan maupun hafalannya bisa dikoreksi oleh ustadz/pengampu secara langsung.

4. Pembinaan tahfidz al-Qur'an dengan menggabungkan antara metode wahdah dengan metode jama', artinya santri di samping menghafal sendiri-diri juga menghafal secara bersama-sama, kemudian muraja'ah-nya disetorkan kepada uztadz/ pengampu tahfidz. Cara yang seperti ini termasuk metode yang efektif dan banyak digunakan oleh para pencinta hafal al-Qur'an. Selain memudahkan penghafal mengkondisikan ayat-ayat yang akan dihafalnya, tetapi juga dapat membentuk gerak refleks pada lisannya karena senantiasa terbayang dalam ingatannya. Cara seperti ini terdapat pada Pondok Pesantren Anshar AlSunnah dan Pondok Pesantren Sabil AsSalam, yang mana ustazd/pengampu tahfidz melaksanakan kegiatan tahfidz secara terprogram dan terpantau, di samping untuk menambah/ memerlancar hafalan juga membaiki bacaan santri.

5. Kegiatan pembinaan tahfidz al-Qur'an menggunakan metode halaqah, di bawah pengawasan seorang musyrif (guru pengampu) per halaqah. Mayoritas santri menghafal ayat per ayat, metode ini dilaksanakan ketika mereka sedang membuat hafalan baru, biasanya mereka terapkan pada waktu dini hari setelah qiyamul lail. Kemudian setoran hafalan di lakukan setelah shalat subuh dengan cara membaca satu-persatu kemudian didengarkan oleh seorang musyrif guna membetulkan bacaan santri dari segi tajwid maupun kelancaran hafalannya, 
sebagaimana terdapat pada Pondok Pesantren Dar As-Salaf.

Meskipun demikian, menurut hemat penulis metode jama' merupakan metode yang efektif dalam penghafalan al-Qur'an, karena santri menghafal ayat-ayat secara kolektif atau bersamasama, dipimpin seorang musyrif (pengampu) kemudian santri mengikuti bacaan musyrif secara berulang termasuk metode yang baik untuk dikembangkan, karena akan dapat menghilangkan kejenuhan, di samping akan membantu menghidupkan daya ingat terhadap ayat-ayat yang dihafalnya.

Sedangkan waktu penghafalan pada masingmasing pesantren dilaksanakan setelah shalat maghrib dan shubuh, karena waktu ini yang lebih efektif. Akan tetapi, biasanya tak jarang para santri menambah waktu untuk muraja 'ah di luar waktu yang telah disediakan, umpamanya 30 menit setelah shalat ashar, atau 30 menit setiap sebelum waktu melaksanakan shalat-shalat fardhu berjama'ah. Bagi santri yang tinggal di asrama maupun tinggal di luar asrama (rumah) wajib menyetor hafalannya. Setoran hafalan tersebut, ustadz pengampu menunjuk santri satu persatu untuk membacakan hafalannya dan diperdengarkan oleh seluruh santri lainnya.

Sementara muraja'ah hafalannya terbagi dua pula; pertama muraja'ah individu dan muraja'ah bersama-sama. Muraja'ah individu tergantung individu masing mengatur jadwal dan waktu untuk muraja'ah-nya. Sedangkan muraja'ah bersama-sama yaitu di dalam kelas dengan beranggotakan kelas itu sendiri. Biasanya waktu muraja'ah adalah setelah semua anggota kelas menyetorkan hafalan ke guru tahfizh-nya dengan cara membaca secara bersama-sama hafalan yang telah mereka hafal.

\section{Faktor Pendukung dan Penghambat Pelaksanaan Tahfidz al-Qur'an di Pondok Pesantren Kabupaten Kampar}

Seperti dimaklumi bahwa kegiatan penghafalan al-Qur'an di pondok pesantren merupakan program penting dan wajib diikuti oleh setiap santri. Pelaksanaan kegiatan penghafalan al-Qur'an tidaklah sama dan semudah mengajarkan mata pelajaran lain. Pembelajaran di pondok pesantren memiliki tujuan untuk membentuk kepribadian muslim seutuhnya dalam mencapai kebahagiaan hidup di dunia dan akhirat. Demikian juga kegiatan tahfidz al-Qur'an, bertujuan agar santrinya menjadi huffadz (para penghafal) al-Qur'an.

Akan tetapi, setiap kegiatan apapun bentuknya pasti ada terdapat faktor pendukung maupun penghambat, baik yang datangnya dari dalam maupun dari luar. Begitu pula dalam kegiatan menghafal al-Qur'an, ada banyak faktor yang mempengaruhi, yaitu berupa faktor pendukung dan ada pula berupa faktor penghambat bagi para penghafal al-Qur'an. Maksud faktor pendukung di sini, penghafal alQur'an lebih memudahkan dirinya dalam menguasai hafalan al-Qur'an yang ia tekuni. Sedangkan faktor penghambat, maksudnya penghafal merasa kesulitan atau merasakan ada hambatan dalam proses menghafal al-Qur'an.

Berdasarkan observasi dan wawancara peneliti, diperoleh informasi bahwa santri yang bersekolah di Pondok Pesantren Kabupaten Kampar tidak semuanya yang tinggal di asrama seperti Pondok Pesantren Daarun Nahdhah. Sebagian santrinya ada yang tinggal di rumah dan sebagian besar lainnya tinggal dalam asrama. Dalam hal ini, peneliti hanya akan mengemukakan faktor pendukung dan penghambat pelaksanaan tahfidz al-Qur'an bagi santri yang tinggal di asrama, termasuk juga pada pondok-pondok pesantren lain yang dijadikan lokasi penelitian.

Dari beberapa penuturan para pengajar/ ustadz pengampu tahfidz di pondok pesantren tersebut, ada beberapa faktor pendukung dan penghambat pelaksanaan tahfidz al-Qur'an, meliputi santri dan tenaga pengajar, metode, serta waktu pelaksanaannya. Untuk lebih jelasnya, 
berikut ini peneliti kemukakan faktor-faktor tersebut, yaitu:

1. Faktor pendukung bagi santri dalam mengikuti kegiatan tahfidz, antara lain:

a. Proses penghafalan dapat dipantau lansung oleh ustadz/pengampu, sehingga hafalan santri akan menjadi lebih mudah disima' atau dikontrol, begitu juga tahsin bacaannya.

b. Selalu termotivasi karena teman-teman yang kesehariannya sama-sama menghafal, sehingga santri mudah untuk saling muroja'ah hafalan antar sesama.

c. Metode tahfidz yang mereka gunakan dapat membantu santri dalam menghafal, karena santri mengahafal ayat per ayat secara sendiri-sendiri maupun secara bersama-sama.

d. Pengaturan waktu menghafal al-Qur'an yang ditetapkan pondok pesantren merupakan salah satu kunci keberhasilan dalam menghafal al-Qur'an, karena di samping dapat menjaga suasana yang kondusif juga para santri memiliki disiplin dalam menghafal al-Qur'an.

Sementara faktor penghambat bagi santri pula dalam mengikui kegiatan tahfidz, antara lain:

a. Sering muncul kemalasan dan kebosanan menghafal al-Qur'an, karena padatnya waktu yang digunakan santri dalam kegiatan formal di sekolah mulai dari pagi hingga siang hari.

b. Kurangnya minat santri muraja'ah hafalan, sehingga santri sering lupa bacaan yang sudah hafal sebelumnya, di samping juga karena kemampuan dan semangat belajar yang tidak sama.

c. Banyak yang mengantuk, terutama di pagi hari sesudah shalat shubuh.

Faktor penghambat seperti disebut di atas, kelihatannya tidak jauh berbeda dengan apa yang diungkapkan oleh Mukhlisoh Zawawie bahwa hambatan-hambatan yang dihadapi oleh calon seorang hafidz adalah sibuk dan tidak memiliki banyak waktu, hati tidak jernih dan kurang fokus karena problematika hidup, bosan dan malas ketika memulai hafalan atau di tengah hafalan, faktor usia, tidak percaya diri karena hafal alQur'an adalah anugerah Allah, lemah ingatan, takut lupa, dan berdosa. ${ }^{14}$

\section{Upaya Mengatasi Hambatan Dalam Pelaksanaan Metode Tahfidz al-Qur'an di Pondok Pesantren Kabupaten Kampar}

Berdasarkan hasil observasi dan wawancara dengan beberapa orang ustadz pengampu tahfidz al-Qur'an, didapatkan informasi bahwa langkah dan upaya yang mereka lakukan untuk mengatasi hambatan dan kekurangan dalam melaksanakan kegiatan tahfidz al-Qur'an, antara lain:

a. Memberikan motivasi dan pembinaan kepada santri agar mereka tetap rajin, bersemangat dan istiqomah dalam menghafal al-Qur'an.

b. Memberikan berupa reward bagi santri yang berprestasi hafal 30 juz, yaitu berupa umroh gratis dan didaftarkan di Universitas Islam Madinah, seperti yang dilakukan oleh pimpinan Pondok Pesantren Anshar AlSunnah.

c. Selain memotivasi dan pembinaan, juga adanya hukuman yang mendidik sifatnya, yaitu tidak akan memberikan ijazah pondok bagi santri yang belum atau tidak menyetorkan hafalan wajibnya kepada uztadz pengampu, seperti yang diterapkan oleh Pondok Pesantren Sabil As-Salam, Daarun Nahdhah, Dar AsSalafy, dan At-Taufiq.

\section{Kesimpulan}

Berdasarkan hasil penelitian dapat disimpulkan bahwa metode Tahfidzl al-Qur'an yang digunakan Pondok Pesantren di Kabupaten

\footnotetext{
${ }^{14}$ Mukhlisoh Zawawie, P-M3 Al-Qur'an Pedoman Membaca, Mendengar, dan Menghafal Al-Qur'an (Solo:Tinta Medina, 2011), 83-88.
} 
Kampar cukup variatif dan baik. Ada yang menggunakan metode wahdah (menghafal per ayat), metode sima'i (menyima' bacaan alQur'an), dan ada pula yang memakai metode jama'i (menghafal bersama-sama). Penerapan metode tersebut cukup efektif, karena di samping memberikan kemudahan bagi santri, juga bisa membuat santri cepat dalam menghafal dan hafalannya bisa lebih terjaga.

\section{Daftar Kepustakaan}

Abdurrabi Nawabuddin. Teknik Menghafal alQur'an. Bandung: CV. Sinar Baru, 1991.

Abdurrahman Assegaf. Pendidikan Islam di Indonesia. Jogjakarta: SUKA Press, 2007.

Ahmad E. Koswara. Metode Efektif Menghafal Al-Qur'an. Jakarta: CV. Tri Daya Inti, t.th.

Ahmad Salim Badwilan. Panduan Cepat Menghafal Al-Qur'an. Yogyakarta: Diva Press, 2009.

Departemen Agama RI. Al-Qur'an dan Terjemahnya. Jakarta: Toha Putra, t.th.

al-Baghdadi, Khatib. al-Jaami'liakhlaqi ar-Rawi wa Adab As-Sami’. Juz I. Beirut: Dar alFikr, t.th.

Hasbullah. Sejarah Pendidikan Islam di Indonesia: Lintasan Sejarah Pertumbuhan dan Perkembangannya. Jakarta: PT. Grafindo Persada, 1999.

Ibn Hanbal, Abu Abdillah Muhammad bin Ahmad. Musnad Imam Ahmad. Juz III. Beirut: Dar al-Fikr, t.th.

Koentjaraningrat. Metode-metode Penelitian Masyarakat. Cet. VII. Jakarta: Sarasin, 1996.

Lexy J. Moloeng. Metode Penelitian Kualitatif. Bandung: Remaja Rosdakarya, 2001.
Marwan Saridjo, dkk. Sejarah Pondok Persantren di Indonesia. Jakarta: Dharma Bhakti, 1982.

Muhaimin Zen. Tata Cara atau Problematik Menghafal Al-Qur'an dan PetunjukPetunjuknya. Jakarta: PT Maha Grafindo, 1985.

Muhammad Quraish Shihab, Dalam Pengantar. Yunan Yusuf. Corak Pemikiran Kalam Tafsir al-Azhar. Jakarta: Pustaka Panjimas, 1990.

Muhammad Yunus. Kamus Arab-Indonesia. Cet ke-3. Jakarta: Hidakarya Agung, 1990.

Mujamil Qomar. Strategi Baru Pengelolaan Lembaga Pendidikan Islam; Manajemen Pendidikan Islam. Jakarta: Erlangga, 2007.

Mukhlisoh Zawawie. P-M3 Al-Qur'an Pedoman Membaca, Mendengar, dan Menghafal AlQur'an. Solo: Tinta Medina, 2011.

Nawabuddin, Abdurrabi. Teknik Menghafal alQur'an. Bandung: CV. Sinar Baru, 1991.

Noeng Muhadjir. Metodologi Penelitian Kualitatif. Cet. 7. Yogyakarta: Rake Sarasin, 2000.

Nur Faizin Muhith. Semua Bisa Hafal Al-Qur'an. Surakarta: al-Qudwah, 2013.

Oemar Hamalik. Metode Belajar dan Kesulitankesulitan Belajar. Bandung: Tarsito,1983.

Perguruan Tinggi Ilmu Al-Qur'an. Beberapa Aspek Ilmiah Tentang Qur'an. Jakarta: Litera Antarnusa, 1986.

al-Qazwini, Abu Abdullah Muhammad bin Yazid bin Majah al-Rabi'i. Sunan Ibn Majah. Juz I. Beirut: Dar al-Fikr, t.th.

Al-Qur'an al-Karim.

Ridwan Nasir. Mencari Tipologi Format Pendidikan Ideal; Pondok Pesantren di Tengah Arus Perubahan. Yogjakarta: 
Pustaka Pelajar, 2008.

Sa'dullah. 9 Cara Cepat Menghafal Al-Qur'an. Depok: Gema Insani, 2012.

Suharsimi Arikunto. Prosedur Penelitian suatu Pendekatan Praktek. Cet. 12. Jakarta: Rineka Cipta, 2002.

Syahruddin, Hanafie, Abdullah Abud S. Mimbar Masjid. Jakarta: CV. Haji Masagung, 1986.
Tim Penyusun. Kamus Besar Bahasa Indonesia. Cet ke-1. Jakarta: Balai Pustaka, 1998.

W. Ahsin Al-Hafizh. Bimbingan Praktis Menghafal Al-Qur'an. Jakarta: Bumi Aksara, 2000.

Az-Zawawi, Yahya Abdul Fattah. Metode Praktis Cepat Hafal Al-Qur'an. Solo: Pustaka Iltizam, 2013. 